\title{
The Role of Energy in Turkish Foreign Policy
}

Muharrem Ekşi *

\begin{abstract}
Energy and foreign policies are intertwined and interact with each other in a globalized world. Probably the role of the energy issues can best be seen in Russian foreign policy. In this article, Turkey's energy needs and the determining role of Turkey's geographical location are evaluated. This article deals with Turkey's energy policies during the JDP (AKP) period with reference to its foreign policy. Turkey's geographical location, energy needs and its related targets and strategies are analyzed. Besides, the energy policy making process and the roles of related actors are assessed. Turkey's position in regional energy projects and its possible gains are analyzed as well.
\end{abstract}

\section{Keywords}

Turkish Energy Policy, Turkish Foreign Policy, Turkish Energy PolicyMaking, BTC, Nabucco, JDP (AKP), Caspian, Blue Stream, South Stream.

* Muharrem Ekşi is a $\mathrm{PhD}$ candidate in the Deparment of International Relations, Ankara University, Ankara, Turkey. 


\section{Introduction}

Turkey which is close to the regions with increasing political significance (Middle East, Caucasia, Central Asia, Mediterranean, Black Sea, Caspian Sea and Gulf) is innately influenced by the global and regional developments. For its close location to global energy basins, Turkey is considered as a transit country between energy producers and consumers in terms of global energy geopolitics. On the other hand, those countries having rich energy reserves but an instable structure enable Turkey to involve in energy and security fields. In other words, Turkey is in a position to both enjoy the advantages and face the risks of her geographical location. Turkish policy makers underline Turkey's strategic significance at every opportunity as a means of foreign policy. But this argument needs to be questioned.

There are some parameters that expose Turkey's geopolitical and geo-economical significance in terms of Eurasian energy geopolitics.

- Turkey is located in a region which contains 71 percent of the World's natural gas reserves and 72 of all oil reserves. ${ }^{1}$

- By 2012, 6-7 percent of the World's oil demands are expected to be transported through Turkey. ${ }^{2}$

- Basic figures indicate Turkey's significance for the Caspian Energy Basin.

- The Caspian Energy Basin contains 4 percent (200 billion barrels) of the World's oil reserves and 5 percent (180 trillion $\mathrm{m}^{3}$ ) of all natural gas reserves. Therefore it is of outstanding importance. ${ }^{3}$

\footnotetext{
1 “Turkey's Energy Strategy", Deputy Directorate General for Energy, Water and Environment, Ministry of Foreign Affairs, January 2009, p. 2, < bttp:/ / www.mfa.gov.tr/data/DISPOLITIKA/EnerjiPolitikasi/Turkey's\%20Energy\% 20Strategy\%20(Ocak\%202009).pdf.>, (access date: 04 November 2009).

2 Ibid., p. 9.

3 "Perspectives on Caspian Oil and Gas Development", IE $A$ Directorate of Global Energy Dialogue, December 2008, p. 5,

<http:// wmw.iea.org/papers/2008/caspian_perspectives.pdf.>, (access date: 04 August 2009).
} 
- The Caspian Energy Basin provides an alternative to the Middle East, for the global markets in general and for the West in particular.

The Caspian Region provides and alternative energy source and an alternative route that enables the West to diversify its energy sources. ${ }^{4}$ In terms of Eurasian energy policies, the Caspian Region became a priority for Turkey's foreign policies. In this context, the basic variables that shape Turkey's energy policies need to be studied in the light of quantitative figures.

\section{Turkey's Current Energy Profile}

First of all, we need to consider Turkey's energy needs, energy strategies and targets as the basic facts that determine its energy policies. Therefore we need to present Turkey's current energy profile. Turkey covers 70 percent of its energy needs through import (Turkey's energy import expenses have reached 34 billion dollars in the first 8 months of 2008 which is more than the total energy import expenses of 2007) 90 percent of Turkey's energy consume is based on fossil fuels. ${ }^{5}$ The figures are expected to increase dramatically in the near future. In this sense, Turkey's dependence in energy export is estimated to increase about 70 percent by 2010 and 80 percent by 2020 . These figures make Turkey dependent; this dependency leads to foreign trade deficit and bring limitations in terms of foreign politics. Turkey's energy consume (which is 110 million tons as of 2008) is expected to increase 6.8 percent annually and reach 171.3 million tons by 2010 . Oil consume is estimated to reach 319 million tons by 2020 and natural gas consume will reach 1400 billion $\mathrm{m}^{3}$ the same year.

\footnotetext{
${ }^{4}$ Robert V. Barylski, "Russia, the West and the Caspian Energy Hub", Middle East Journal, Vol. 49, No.2 (Spring 2005), pp. 217-232.

5 Yusuf Yazar \& Hasan Hüseyin Erkaya, "Turkey: Energy Status and Expectations", SETA Policy Brief, No. 6 (January 2008), p. 1,

< http:// wnw.setav.org/document/Policy_Brief_No_6_Yusuf_Yazar.pdf?phpMyAdmin=e 008732753 bf014f26cf3b79aa21f1f1>. (access date: 02 December 2009).
} 
Turkey covers 30 percent of her energy needs from her own sources. The domestic energy needs of Turkey are covered from coal (29 percent), oil (33 percent), natural gas (30 percent) and hydraulic energy (32 percent). ${ }^{6}$

The figures indicate that Turkey is facing a lack of energy and dependence in its energy policies. In this context, Turkey needs to overcome these facts to settle its energy policies. In parallel to its energy consume, Turkey's asymmetrical dependence is growing as well which is perceived as a security matter. In this regard, there can be three ways to reduce Turkey's external dependence; diversity of sources, multiple pipelines and nuclear energy. The Turkish Foreign Ministry also mentioned the external dependence issue which is growing due to increasing energy demands and stated that they adopted diversification of sources and pipelines as their concept. ${ }^{7}$ In order to cover its needs, Turkey is interested in being the bridge between the Caspian energy sources and the World markets, becoming a transit country for the West's energy security issues and making strategic gains out of this situation. ${ }^{8}$

\section{The Basics of Energy Policies in Terms of the Turkish Foreign Policy}

The principles that shape Turkey's energy policies are closely related with the foreign policy principles. Turkish foreign policy structure has been undergoing a radical change since 2002 when the Justice and Development Party (JDP, AKP) ${ }^{9}$ came to power

\footnotetext{
${ }^{6}$ Necdet Pamir, 'Dünya'da ve Türkiye'de Enerji, Türkiye'nin Enerji Kaynakları ve Enerji Politikaları", Metalurji Dergisi, (May 2009), p. 11,

<http:// wnw.metalurï.org.tr/dergi/dergi134/d134_73100.pdf.> (access date: 24 November 2009).

7 “Turkey's Energy Strategy...”, p. 2.

8 Daniel Fink, "Assessing Turkey's Future as an Energy Transit Country", the

Washington Institute for Near East Policy, (July 2006), p. 1-8.

9 "Energy", JDP Program,
} 
and Ahmet Davutoğlu (current foreign minister) began to shape the Turkish foreign policy according to his book. ${ }^{10}$ The reflections of the "zero problems with neighbors" policy and "maximum cooperation" which is the further step of this policy can also be seen in the recent Turkish energy policies. ${ }^{11}$ Besides, the geopolitics based foreign policy principles dominate the energy policies. The passive and uniaxial foreign policy understanding seems to have been replaced by a multidirectional, dynamic and active diplomacy which is pursued in parallel to the energy policies. The above explained new energy policy principles indicate that the energy policies of the JDP are structured on four main bases which are; maximum benefit, geopolitical location, cooperation and multiple pipelines. The first principle is based on making maximum gains from neighboring countries and nearby energy basins. This pragmatic understanding in energy policies is aiming to increase benefits to a maximum level. Utilizing the strategic location and becoming a transit country between the producers and the consumers determining the routes of pipelines is embraced as the main principle. This principle is practiced by using Turkey's geopolitical location as a marketing tool in pipeline policies. This geopolitical based policy can be considered as the reflection of the geographical-determinist understanding in foreign and energy politics.

Instead of the zero-sum game approach, a new cooperation understanding is adopted in Eurasian energy policies and mutual win-win strategies are preferred in this manner. Therefore, Turkish-Russian relations are also developing in a different way; cooperation policies are embraced instead of the competition and blocking policies of the 1990's. The Nabucco project which was

<bttp:// eng.akparti.org.tr/english/partyprogramme.html\#3.10.>, (access date: 28 December 2009).

10 Ahmet Davutoğlu, Stratejik Derinlik: Türkiye'nin Uluslararası Konumu, 21 ${ }^{\text {st }}$ ed., İstanbul, Küre Press, 2004.

11 Ahmet Davutoğlu, “Turkey's Foreign Policy Vision: An Assessment of 2007”, Insight Turkey, Vol. 10, No. 1, pp. 77-96,

<http:// wmw.insightturkey.com/Insight_Turkey_10_1_A_Davutoglu.pdf.>, (access date: 30 December 2009). 
developed in the 90's to break Russian monopoly on pipelines and reduce Europe's dependency on Russia. ${ }^{12}$

Today, Turkey invites Russia to become a part of the Nabucco project as a part of its new cooperation policies. ${ }^{13}$ For instance, it is planned that Nabucco will get 10 percent gas from Russia. Russia on the other hand, invited Turkey to be a member of the South Stream project which was initiated against the Nabucco. ${ }^{14}$ This indicates that the Turkish-Russian relations are undergoing a dramatic change. The multiple pipeline policy which can be considered as the reflection of the multi-dimensional foreign policies has become one of Turkey's principles. Turkey aims to become the East-West and North-South energy corridor.

\section{Energy Strategy and Targets}

When we examine the strategy documents of Turkish energy institutions ${ }^{15}$, we see the below mentioned common parameters in each of them:

- To maintain sufficient, cheap, continuous, sustainable and environmental-friendly energy based on energy security.

\footnotetext{
12 Niklas Norling, "Gazprom Monopoly and Nabucco Potentials: Strategic Decision for Europe", Silk Road Paper, (November 2007), p. 6, <http:// www.isdp.eu/files/publications/srp/07/0711Nabucco.pdf.>, (access date: 12 July 2009).

13 "Turkey hopes Russia, Iran will join Nabucco gas pipeline Project", RiaNovosti, 13 July 2009, <http:// en.rian.ru/world/20090713/155511983.html.> (access date: 14 December 2009).

14 "Turkey to approve construction of South Stream pipeline", RiaNovosti, 5 August 2009, <http:/ / en.rian.ru/ russia/20090805/155735283.html.>, (access date: 16 December 2009).

152007 Annual Report, Turkish Petroleum Cooperation (TPAO), <http://wnw.tpao.gov.tr/v1.4/condocs/tpao_rp08.pdf>; 2008 Annual Report, Petroleum Pipeline Cooperation (BOTAȘ),

<bttp:// wnw.botas.gov.tr/icerik/_docs/faalrapor/2008/tur/fr2008_full.pdf>; 2008 Annual Report, Republic of Turkey Ministry of Energy and Natural Resources, <http:// wmw.enerji.gov.tr/yayinlar_raporlar/2008_faaliyet_raporu.pdf.>, (access date: 25 December 2009).
} 
- O cover energy needs from domestic and renewable energy sources and to intensify R\&D studies to this end.

- Diversification in energy sources and pipelines.

- To replace natural gas power plants with nuclear power plants as a part of diversification policies.

- Liberalization of the energy sector, maximizing productivity.

- To secure supplies by increasing storage systems.

- To increase productivity and apply energy saving measures (the adaptation of the energy productivity law in 2007 in the Assembly is promising in this manner).

\section{Targets}

The targets $^{16}$ of the Turkish Energy Policies can be summarized as:

- To become an energy corridor. (Not only between the East and West but also between the North and South).

- Utilizing the geopolitical location to become a transit country and the $4^{\text {th }}$ main arterial road and to integrate with the EU energy markets.

- To become an energy hub and make Ceyhan a significant port just like Amsterdam in the long term. To make Ceyhan the energy distribution center of global energy markets.

In a nutsell, Turkey's energy strategy is aimed to cover the energy needs independently, at least on paper. The theoretical backgrounds for above mentioned targets are ready and are waiting to be practiced.

16 “Turkey’s Energy Strategy...", p. 2. 


\section{Energy Policy-Making: Actors and Functions}

Three factors are involving in the energy decision-making process $^{17}$ which are; governmental, non-governmental and international bodies. The governmental bodies are the Prime Ministry, Ministry of Energy, Foreign Ministry, Treasure, State Planning Office, Turkish Atomic Energy Agency (TAEA), Turkish Electricity Trade and Contracting Corporation (TETAS), The Scientific and Technological Research Council of Turkey (TUBITAK), the state intelligence service (MIT), Turkish Armed Forces and the National Security Council (MGK). Private corporations and NGO's are the non-governmental bodies. Other states, their energy policies, NGO's, INGO's and Multinational Corporations are the international bodies that involve in the energy policy making process.

The above mentioned actors should also be evaluated according to their roles in the process. The Prime Ministry is involved in policy making, planning and management of the tender processes, guidance and legislation. The Ministry of Energy is involved in the whole process and undertakes coordination and determination of political targets. The Foreign Ministry decides for the protocols, integrates the protocols into the energy policies and foreign policies, publicity, communication, information, national and international security and guidance. TAEA is involved in advertising and publicity, communication, information, technical control and inspection. TETAS deals with exploitation and finance issues. Armed Forces and MGK determine the policies, pressure and guidance tools, international and national security issues but the influence of the Armed Forces has reduced in the JDP period in general. TUBITAK deals with issues such as technology transfer and R\&D. State Planning Office does the financial modeling, legislation planning and planning of tender processes. The Treasure deals with finance and trade. MIT is involved in intelligence, security and technology transfer. Corporations and

17 Hakan Akbulut, "Energy Decision-Making: The Turkish Case", Perceptions, Vol. 5, (September-November 2000), pp. 1-6. 
international actors are involved almost every step of the process. Institutions like TPAO and BOTAS are acting as experts and are involved in the policy making process. Besides of these, a state institution is planned to be established in order to do the coordination in fields such as energy evaluation, inspection, exploitation, legislation, standardization, technical control and tender processes.

\section{Benefits of Energy Policies}

Turkey's benefit areas reach to Caspian Basin and the Gulf. Relations with Azerbaijan, Kazakhstan, Russia, Iraq, Saudi Arabia and Iran play an important role. Turkey's target to diversify energy sources makes the Caspian Basin a priority region for Turkey. Being a transit country between the Caspian energy sources and the West and being able to trade some of the energy is also a part of the plan. In the Gulf region, Turkey wants to develop relations with Iraq to achieve integration and establish cooperation in the field of energy. The Kirkuk-Yumurtalik pipeline will articulate Turkey to the Gulf and enables Turkey to reach the Middle Eastern oil reserves easily. ${ }^{19}$

Turkey chose to attach interest to the Caspian Region in order to reach its aims. In this particular age, Turkey casted itself the energy bridge role and build its foreign policy within this framework. Turkey's plan to become an "Energy Bridge" includes evolving into an energy corridor with the help of the EU and the US in particular. ${ }^{20}$ In this context, the Baku-Ceyhan-Tbilisi (BTC)

18 Bülent Alirıza, “Turkey’s Caspian Energy Quandary”, Caspian Energy Update, 13 August 2008, <http://csis.org/files/media/csis/pubs/cen020813.pdf.>, (access date: 22 June 2009).

${ }^{19}$ Lenore G. Martin, "Turkey and Gulf Cooperation Council Security", Turkish Studies, Vol. 10, No. 1 (March 2009), pp. 75-93.

20 Mehmet Öğütçü, "Turkey's Energy Policies: In the Context of Eurasian Geopolitics", Harvard Belfer Center, Caspian Studies Program, $<$ bttp:// belfercenter.ksg.harvard.edu/publication/12786/turkeys_energy_policies_in_the_co ntext_of_eurasian_geopolitics.btml.>, (access date: 17 December 2009). 
pipeline was of great importance. The BTC formed the first step of the East-West energy corridor. The BTC didn't only serve as a pipeline; it also connected the related countries in terms of foreign politics and accelerated the Turkish-Russian competition. ${ }^{21}$ With the support of USA, until 2003 but particularly in the 90's, Turkey acted as a bridge and went into competition with Russia. After 2003 Turkey changed its policy and established cooperation instead of competition to make gains in the field of energy. In August 2009, Turkey and Russia signed 20 agreements, most of them about energy issues. ${ }^{22}$ The trade volume between the two countries have grown 8 times from 2000 to 2008 and reached 40 billion Dollars as a result of the cooperation policies. The nearby developments prove that energy became one of the leading factors of the Turkish Foreign Policy.

Projects such as the Nabucco and South Stream are shaping Turkey's relations with USA, EU, Russia and Azerbaijan. Recently, there is a visible competition between the Nabucco and South Stream projects to carry Caspian resources to the West. ${ }^{23}$ Turkey will make its choice in favor of one project and that choice will probably determine the Eurasian energy routes and re-shape Turkey's relations. Therefore, while Russia invited Turkey to become a member of the South Stream Project which is led by Russia, EU states acted faster and opened the Nabucco project to sign on July 13, 2009 in Ankara and subsequently, Nabucco finally came true. Turkey lands in the midst of an energy competition due to these developments. Nevertheless Turkey cannot opt for one of these projects and it has to pursue a multidimensional policy, similar to its recent foreign policy path. Turkey's choices

\footnotetext{
21 Katinka Barysch, "Pipeline, Politics and Power", CER, October 2008, < bttp:// www.cer.org.uk/pdf/rp_851.pdf.>, (access date: 09 November 2009).

22 "Turkey and Russia: A Strategic Choice", Editorial, EurasiaCritic, September 2009, <http:// mnw.eurasiacritic.com/articles/turkey-and-russia-strategic-choice.>, (access date: 06 December 2009).

23 "South Stream, Nabucco competition escalates", SETimes, 1 June 2009, <http:// www.setimes.com/cocoon/setimes/xhtml/en_GB/features/setimes/articles/2009/ 06/01/reportage-01.>, (access date: 04 November 2009).
} 
will not only determine for the energy routes but also for its foreign affairs.

\section{Conclusion}

As a result, the dependency in Turkish energy policies and increasing energy demands are creating serious problems for Turkey. Supplying the energy from reliable foreign sources and through diverse pipe lines are Turkey's recent energy policy principles. In this context, diversification of supplies and improvement of domestic production are set as targets. Turkey is the potential East-West energy corridor with BTC and NorthSouth energy corridor with the Samsun-Ceyhan pipeline of the Blue Stream. But it is obvious that Turkey will not be the sole East-West energy corridor with BTC. Besides, the Blue Stream will not be extended to Israel which means Turkey lost its chance to become the sole North-South energy corridor. Lack of integration among Turkish energy, security and foreign policies and lack of close relations with Caspian States are the bottlenecks of the Turkish energy policy. The Turkish energy policy that lacks a comprehensive strategic planning is drawing zigzags in relation to conjectural developments. 